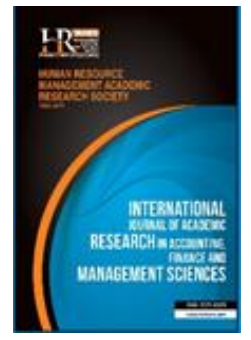

International Journal of Academic Research in Accounting, Finance and Management Sciences

Vol. 8, No.1, January 2018, pp. 215-223

E-ISSN: 2225-8329, P-ISSN: 2308-0337

(C) 2018 HRMARS

www.hrmars.com

To cite this article: Alqatamin, R.M. (2018). Do Family-Owned Companies Achieve High or Low Performance? Evidence from Jordan, International Journal of Academic Research in Accounting, Finance and Management Sciences, 8 (1): 215-223.

\title{
Do Family-Owned Companies Achieve High or Low Performance? Evidence from Jordan
}

\author{
Rateb Mohammad ALQATAMIN \\ Accounting Department, Business Faculty, Tafila Technical University, Jordan, \\ E-mail: rqatamin@ttu.edu.jo
}

\begin{abstract}
This paper examines the relationship between family ownership and corporate performance. The study uses $R O A$ to measure the level of performance and employs random-effect and panel data regressions to examine the relationship. The sample consists of 495 firm-year observations over the study period 2014-2016. In general, this study introduces new empirical evidence suggesting that managers in family companies are more likely to achieve high performance than those managing non-family companies. The results of this study could be beneficial for several users of financial information, such as regulators, investors, auditors and lenders. These users might consider the findings of this study when using a company's financial information, and consequently enable them to make better decisions. Thus, this study introduces new empirical evidence about the ownership structure in Jordan, since a large proportion of companies are family controlled.

Key words Family-owned companies, non-family companies, performance, Jordan, ASE

Received: 15 Mar $2018 \quad$ (C) The Authors 2018

Revised: 30 Mar $2018 \quad$ Published by Human Resource Management Academic Research Society (www.hrmars.com)

Accepted: 15 Apr 2018 This article is published under the Creative Commons Attribution (CC BY 4.0) license. Anyone may reproduce, distribute, translate and create derivative works of this article (for both commercial and non-commercial purposes), subject to full attribution to the original publication and authors. The full terms of this license may be seen at: http://creativecommons.org/licences/by/4.0/legalcode
\end{abstract}

\section{Introduction}

A family company is one in which members of the founding family continue to hold positions in top management, either as top executives or as directors, or are blockholders in the company (Chen et al., 2008; Habbershon et al., 2003). Compared to non-family companies, family companies face fewer agency problems that arise from the separation of management and ownership (type one agency problem), due to the latter being better able to monitor managers (Lubatkin et al., 2005). Furthermore, family shareholders have more long-term investment orientation than other types of owner (Chen et al., 2008). These characteristics of family companies raise interesting issues about their performance. Previous studies found that managers in family companies are more likely to achieve high level of performance than those managing non-family companies (Anderson and Reeb, 2003a; Espinoza and Espinoza, 2012).

Previous studies employed agency theory to explain the performance level of the different forms of ownership structure and build on two types of agency problem that arise from the differences in ownership structure (e.g. Al-Akra and Hutchinson, 2013; Wan-Hussin, 2009). The first type of agency problem focuses on conflicts between managers and owners, while the second deals with conflicts between controlling shareholders and minority shareholders (Cucculelli et al., 2014; De Massis et al., 2015). Thus, theoretically, there are two contradictory perspectives regarding the relationship between family companies and their performance: the convergence of interest and the management entrenchment perspectives (Morck et al., 1988). Convergence of interest between the owners and outside investors occurs when the owner's holding 
in significant; an increase in the owner's holding will reduce stockholders' needs to monitor insiders. On the other hand, in family companies, the management entrenchment perspective assumes that the founding family may have a high proportion of equity in the company; this control gives them power to seek private benefit at the expense of minority shareholders.

These limitations provide the motivation for the present study, to bridge this gap in the literature by providing evidence on the nature of the relationship between company performance and family ownership, in the context of Jordan. The study introduces new empirical evidence suggesting that managers in family companies are more likely to achieve high performance than those managing non-family companies. These findings should be of interest to policymakers, regulators and academics regarding the impact of family ownership on the level of performance, not only in Jordan but also in other developing countries. Further, the findings of this study are likely to be of interest to investors since they introduce new empirical evidence about the ownership structure in Jordan, where a large proportion of companies are family controlled. One hundred and twelve (68\%) of companies listed on the ASE over the period 2014-2016 were family owned (ASE, 2017). Thus, this setting in Jordan provides an opportunity to examine empirically this relationship in a market where highly concentrated family-controlled ownership is commonplace. In addition, Jordan has introduced numerous reforms of accounting regulations, securities exchange laws and corporate governance practices. These reforms contribute to more transparent markets and have resulted in the listed companies enhancing their performance.

The current study is expected to offer incremental contributions to the literature on company performance and ownership structure in different ways. First, it demonstrates the applicability of ownership structure theory in developing countries like Jordan. Second, to the best of my knowledge, this study presents the first evidence that extends the existing literature by examining the relationship between the level of performance and family-controlled companies as a central issue in Jordan.

\section{Literature review}

Ali et al. (2007) argue that family-controlled firms have several characteristics that reduce agency problem type I (the conflict that arises between managers and shareholders). The controlling family tends to have a stronger motivation to oversee managers than do minority owners. Second, families are more likely to be engaged in management and have better information about their investment. Third, controlling families tend to have a longer-term investment orientation than minority shareholders as they have more self-interest in the firm (Minichilli et al., 2010). Given these attributes, in family companies managers might be motivated to achieve higher performance than managers of non-family companies. In this regard, Anderson and Reeb (2003b) and Espinoza and Espinoza (2012) found that USA and Mexican family companies are more likely to achieve better performance than non-family controlled companies. Anderson and Reeb (2003b) empirically examined the association between the level of corporate performance and the proportion of family ownership among SandP500 for the year 2003. Their findings indicated that firm with a high percentage of family ownership performed better than non-family firms. In addition, using a sample of 675 publicly traded corporations listed in 11 countries in Continental Europe during the year 1999, Barontini and Caprio (2006) revealed that companies with a large proportion of family ownership achieve a higher level of performance than those with low family ownership. Moreover, Espinoza and Espinoza (2012) found that managers in family companies provide better performance than managers of non-family companies, their results suggesting that family owners improve the level of company performance. Schulze et al. (2003) suggest that the family manager will make decisions that favour profits and profitability for their family company and thus benefit their family. Therefore, the corporate performance of family companies differs from non-family companies, being higher (Miller and Breton-Miller, 2006). This argument is largely corroborated by previous literature that provides consistent support for the idea that family companies are strongly associated with better performance (Villalonga and Amit, 2006). A study conducted by Arosa et al. (2010) indicates that Spanish non-listed family companies have a positive impact on company performance.

Conversely, Giovannini (2010) argued that family ownership is more likely to impede performance, since firms with a controlling family tend to make less transparent disclosures in their annual reports. The underlying rationale is that family owners do not have the need or motivation to use control-enhancing 
governance mechanisms to increase their power (Memili et al., 2015). Consistent with this argument, Peng and Jiang (2010) suggest that the impact of family ownership on company value is associated with the level of shareholder protection ensured by national legal and regulatory institutions. Therefore, managers have less power to achieve a high level of performance than their peers in non-family companies (Memili et al., 2015). Similarly, Chen et al. (2008) examined the impact of family ownership structure on performance among Italian companies during 2001. Their findings showed that management of family companies has a negative impact on the firm's performance, suggesting that non-family companies are more likely to achieve high performance.

Overall, previous studies document that in extremely concentrated family ownership situations, the influence on company performance is more complicated and can be viewed from two perspectives: management entrenchment and convergence of interest (Morck et al., 1988).

Therefore, we propose the following competing hypotheses:

$H_{1}$ : the proportion of family companies is positively associated with firm performance.

$\mathrm{H}_{2}$ : the proportion of family companies is negatively associated with firm performance.

\section{Methodology of research}

\subsection{Data source and sample}

The study used data collected from the ASE, which lists 243 companies divided into financial, industrial and service sectors. However, all financial companies $(n=43)$ were excluded from the initial sample due to their unique characteristics and specific regulatory framework, which may have an impact on the results (Alqatamin et al., 2017; Athanasakou and Hussainey, 2014). In addition, industrial sectors comprising fewer than six firms, and companies with missing data, were removed (Katmun, 2012). Thus, the final sample consisted of 495 firm-year observations over the study period 2014-2016, as shown in Table 1; Table 2 indicates the distribution by type of industry. This study adopted the three-year period 2014-2016 as in recent years a series of privatisation schemes have been put in place to lower the amount of government influence on the Jordanian economy (Al-khabash and Al-Thuneibat, 2008). The study period ended in 2016 as data for subsequent years were unavailable. All data relating to the study variables were collected from the companies' annual reports published for 2014-2016. Each annual report was scanned manually. Most are published on company websites, and are released within the first the quarter of the year following the previous financial year-end. Annual reports are considered more easily comparable among companies than other less formal communication channels such as press releases or direct contact analysis (Alqatamin et al., 2017). However, the websites of the Securities Depository Centre (SDC), the ASE itself and the OSIRIS database were used as additional sources to cover any financial information missing from the annual reports.

Table 1. Sample Description

\begin{tabular}{|c|c|c|c|c|}
\hline Description & 2014 & 2015 & 2016 & Pooled \\
\hline Initial Sample & 243 & 243 & 243 & 729 \\
\hline \multicolumn{5}{|l|}{ Excluded: } \\
\hline Financial industries & 43 & 43 & 43 & $(129)$ \\
\hline Non-financial industries & 200 & 200 & 200 & 600 \\
\hline \multicolumn{5}{|l|}{ Industries with fewer than six firms } \\
\hline Health Care & 4 & 4 & 4 & 12 \\
\hline Technology and Communication & 1 & 1 & 1 & 3 \\
\hline Media & 2 & 2 & 2 & 6 \\
\hline Paper and Cardboard & 3 & 3 & 3 & 9 \\
\hline Utilities and Energy & 3 & 3 & 3 & 9 \\
\hline Printing and Packaging & 1 & 1 & 1 & 3 \\
\hline Tobacco and Cigarettes & 2 & 2 & 2 & 6 \\
\hline Glass and Ceramic Industries & 1 & 1 & 1 & 3 \\
\hline \multirow[t]{2}{*}{ Electric Industries } & 4 & 4 & 4 & 12 \\
\hline & & & & (63) \\
\hline Firms with unavailable data & 14 & 14 & 14 & $(42)$ \\
\hline Final Sample & 165 & 165 & 165 & 495 \\
\hline
\end{tabular}


Table 2. Final distribution of the sample by industry

\begin{tabular}{|c|c|c|}
\hline Description & Number & Percentage \\
\hline Educational services & 15 & $9 \%$ \\
\hline Hotels and tourism & 41 & $25 \%$ \\
\hline Transport & 18 & $11 \%$ \\
\hline Commercial services & 12 & $7 \%$ \\
\hline Pharmaceutical and medical industries & 12 & $7 \%$ \\
\hline Chemical industries & 10 & $6 \%$ \\
\hline Food and beverages & 13 & $8 \%$ \\
\hline Mining and extraction industries & 14 & $9 \%$ \\
\hline Engineering and construction & 17 & $10 \%$ \\
\hline Textiles, leather and clothing & 13 & $8 \%$ \\
\hline Total & 165 & $100 \%$ \\
\hline
\end{tabular}

\subsection{Measurement of variables}

\subsubsection{Dependent variable}

Previous researchers on company performance have used different proxies to measure firm performance, such as ROA, ROE, efficiency; all have been used in previous studies testing for the effect of family ownership structure on company performance (Kim and Rasiah, 2010). Stock price and dividend payable have also been used to measure performance (Ponnu, 2008). With no consensus on the best method of measuring performance (Ntim and Oseit, 2011), ROA was selected as it is the most widely accepted and is used by regulators in measuring performance and the profitability of investment projects made using acquired deposits (Kallamu and Saat, 2015). In addition, ROA is a suitable measure of performance as it reflects the ability of the company to generate returns on its portfolio of assets and is not affected by changes in the equity market (Hutchinson and Gul, 2004). Furthermore, ROA is preferable in the context of a corporate governance study because it reflects the ability of the management in utilising the company's assets and other resources to generate profit and add value to the company (Sufian and Habibullah, 2010). Following previous studies (Al-Saidi and Al-Shammari, 2013; Kallamu and Saat, 2015; San Ong and Gan, 2013), this study used ROA as a proxy for company performance, measured as profit before tax at the year-end divided by total assets (Praptiningsih, 2009).

\subsubsection{Independent and control variables}

We divided the sample into family and non-family company groups using the Companies Control Department classification, in which a company is defined as a family company if the family or an individual holds $10 \%$ or more of the equity (ASE, 2017). Therefore, family company is a dummy variable assigned a value of one if it meets this criterion, and zero otherwise (Chen et al., 2016). This was recommended by previous studies Wang (2006) and Al-Akra and Hutchinson (2013), which noted that the effect of families on company affairs might go beyond the common shares they own. To control company and governance attributes that have an effect on performance, the study adds the company size, dividends, leverage, board size, duality, board independence, managerial ownership, and institutional ownership. Previous studies have suggested that these variables may affect performance (Arosa et al., 2010; Villalonga and Amit, 2006; Wang, 2006). The following model is estimated to investigate the relationship between performance and family-controlled companies. Table 3 provides the definitions and measurements of all variables. Equation (1) summarises the empirical model.

FPERFOM $_{\mathrm{it}}=\beta_{0}+\beta_{1}$ FAMI $+\beta_{2}$ FSIZE $+\beta_{3}$ FDIVID $+\beta_{4}$ FLEVER $+\beta_{5}$ BOARDSI $+\beta_{6}$ BOARDD $+\beta_{7}$ BOARDI $+\beta_{8}$ MANAOW $+\beta_{9}$ INSTITOW + Industry Controls + Year Controls $+\varepsilon_{\mathrm{i}}$.

Where:

$\beta_{0}=$ The regression intercept.

$\beta_{1} \ldots \ldots . . . \beta_{9}=$ The regression coefficients.

$\varepsilon=$ The error term. 
Table 3. Variable definitions and measurements

\begin{tabular}{|c|c|c|}
\hline Label & Variable & Description \\
\hline PERFORM & Firm's Performance & $\begin{array}{l}\text { ROA as a proxy for company performance, measured as profit before } \\
\text { tax at the year-end divided by total assets. }\end{array}$ \\
\hline FAMI & Family Company & $\begin{array}{l}\text { Measured by the proportion of total shares owned by the family. } \\
\text { Dummy variable would take one if a family or individual holds } 10 \% \text { or } \\
\text { more of equity, and zero otherwise. }\end{array}$ \\
\hline FSIZE & Firm Size & The natural log of a firm's total assets. \\
\hline FDIVID & Dividends Ratio & Cash dividends divided by net income for the same period. \\
\hline FLEVER & Leverage Ratio & Measured by total liabilities divided by total assets. \\
\hline BOARDSI & Board Size & Measured by the total number of board members. \\
\hline BOARDD & Board Duality & $\begin{array}{l}\text { A dummy variable that takes the value of one if the CEO and chairman } \\
\text { are the same person and zero otherwise. }\end{array}$ \\
\hline BOARDI & Board Independence & Measured by the total number of outside directors. \\
\hline MANAOW & Managerial Ownership & $\begin{array}{l}\text { Measured by the proportion of total shares held by executive directors } \\
\text { divided by the total number of shares. }\end{array}$ \\
\hline INSTITOW & Institutional Ownership & $\begin{array}{l}\text { Measured by dummy variable, taking the value one if any institutional- } \\
\text { held shares and zero otherwise. }\end{array}$ \\
\hline
\end{tabular}

\section{Results and Discussions}

\subsection{Descriptive Statistics}

Table 4 describes the total observations, mean, standard deviation, minimum and maximum values for all variables used in this study. The dependent variable is the company's performance. As can be seen from the table, the minimum value of performance of firms is 0 and the maximum is 0.666 , which indicates a considerable dispersion in the rates; the mean value of 0.206 shows a generally low level of performance across the companies. This study employed the mean value as a benchmark to classify high and low levels of performance. This figure is similar to those obtained by other researchers (Alqatamin, 2018; LückerathRovers, 2013).

In terms of family and non-family companies, Table 4 shows that the minimum value is 0 and the maximum 0.999 with standard deviation 0.213 . In respect of the control variables, the company size value indicates a wide range, from .930 to 3.231 . The results reveal that the mean of dividends ratio is 0.168 ; minimum and maximum values are 0 and 0.905 respectively. The leverage ratio has a mean value of 0.168 and a range 0 to .935 , with standard deviation 0.317 . Board size has a mean value of 8.363 , which is relatively consistent with the number reported by (Alqatamin, 2018). However, the maximum board size is 16 members, which indicates that, in general, Jordanian firms do not follow the Jordanian Corporate Governance Code number 15, which recommends that board size should be not more than 13 members. A dummy variable of board duality has a mean of 0.207 , and board independence of 0.764 . In terms of ownership structure, managerial and institutional ownership have mean values of 0.040 and 0.365 respectively.

Table 4. Descriptive analysis

\begin{tabular}{lccccc}
\hline \multicolumn{1}{c}{ Variables } & Observations & Minimum & Maximum & Mean & Std. Deviation \\
\hline FPERFOM & 495 & 0 & .666 & .206 & .118 \\
FAMI & 495 & 0 & .999 & .166 & .213 \\
FSIZE & 495 & .930 & 3.231 & 5.550 & 1.570 \\
FDIVID & 495 & 0 & .905 & .168 & .111 \\
FLEVER & 495 & 0 & .935 & .168 & .317 \\
BOARDSI & 495 & 3 & 16 & 8.363 & 2.471 \\
BOAEDD & 495 & 0 & 1 & .207 & .406 \\
BOARDI & 495 & 0 & 2 & .764 & .798 \\
MANAOW & 495 & 0 & .718 & .040 & .107 \\
INSTITOW & 495 & 0 & 1 & .365 & .302 \\
\hline
\end{tabular}




\subsection{Multicollinearity}

A correlation coefficients matrix was used to check for the incidence of multicollinearity between independent variables, as employed extensively in previous studies (Alqatamin et al., 2017; Kallamu and Saat, 2015). Table 5 shows that the highest correlations between company size and board duality, with a coefficient of $54 \%$. Therefore, the multicollinearity problem does not exist among the data set used in this study.

Table 5. Correlation Matrix

\begin{tabular}{lccccccccc}
\hline \multicolumn{1}{c}{ Variables } & FAMI & FSIZE & FDIVID & FLEVER & BOARDSI & BOARDD & BOARDI & MANAOW & INSTITOW \\
\hline FAMI & 1.000 & & & & & & & & \\
FSIZE & -.143 & 1.000 & & & & & & & \\
FDIVID & -.042 & .099 & 1.000 & & & & & & \\
FLEVER & .001 & .078 & .013 & 1.000 & & & & & \\
BOARDSI & -.109 & .353 & -.004 & .116 & 1.000 & & & & \\
BOARDD & .224 & -.541 & -.028 & .037 & -.161 & 1.000 & & & \\
BOARDI & .034 & .033 & -.013 & .133 & -.105 & .080 & 1.000 & & \\
MANAOW & .445 & -.084 & -.041 & .119 & -.139 & .314 & .116 & 1.000 & \\
INSTITOW & .482 & .015 & .037 & -.080 & -.117 & -.104 & .015 & -.224 & 1.000 \\
\hline
\end{tabular}

\subsection{Univariate T-Test}

Table 6 presents the descriptive analysis for family versus non-family companies. There were 112 (68\%) family companies and 53 (32\%) non-family companies listed on the ASE over the period 2014-2016. The t-statistic shows that the coefficient for the difference between the performance in family and nonfamily companies is positive and significant at the $4.7 \%$ level. The mean performance of family companies is $35 \%$ percent, higher than non-family companies' $34 \%$, and it is positive and significant from zero at the level $(\mathrm{P}<.047)$. This finding suggests that family-controlled companies are more likely to provide a higher level of performance than non-family controlled companies.

Table 6. Univariate t-test for family versus non-family companies 2014-2016

\begin{tabular}{lcccccc}
\hline & \multicolumn{2}{c}{ Family companies } & \multicolumn{2}{c}{$\begin{array}{c}\text { Non-family companies } \\
\mathbf{N = 5 3}\end{array}$} & \multicolumn{2}{c}{ Differences } \\
\hline Variables & Mean & Sd. & Mean & Sd. & T-Values & P-value \\
PREFOM & .352 & .182 & .342 & .158 & 1.564 & $.047^{* *}$ \\
FSIZE & 6.435 & 6.652 & 6.855 & 7.45 & -5.213 & $.001^{* * *}$ \\
FDIVID & .186 & .406 & .185 & .365 & .398 & .723 \\
FLEVER & .294 & .163 & .278 & .158 & 2.12 & $.028^{* *}$ \\
BOARDSI & 6.846 & 2.431 & 8.760 & 2.58 & -3.58 & .667 \\
BOARDD & .254 & .428 & .1615 & .387 & 3.198 & $.001^{* * *}$ \\
BOARDI & 1.945 & 1.359 & 2.165 & 1.176 & -2.83 & $.007^{* * *}$ \\
MANAOW & .537 & .198 & .028 & .0761 & 5.569 & $.001^{* * *}$ \\
INSTITOW & .280 & .429 & .548 & .276 & 4.988 & $.001^{* * *}$ \\
\hline
\end{tabular}

\subsection{Regression Analysis}

To achieve the study's aim and investigate the relationship between family companies and the level of performance, a panel regression random effect method was used; the results are presented in Table 7. The $R^{2}$ value is $41 \%$, which means that the independent variable demonstrates $41 \%$ of the variation in the dependent variable. The $P$-value is highly significant at level 0.00 , meaning that the model itself is highly significant and thus has good explanatory power to achieve the study aim. The analysis of results shows a significant and positive relationship between family companies and the level of performance at the level $(P<$.029). Our results are consistent with the agency theory perspective (management entrenchment), and with Anderson and Reeb (2003b) who found that family companies achieve higher performance than nonfamily companies. Furthermore, Espinoza and Espinoza (2012) examined the relationship between the 
extent of performance and percentage of family ownership among Mexican family listed companies; their findings indicated that a high percentage of family ownership is associated with higher performance. In addition, our results are consistent with those of Arosa et al. (2010) who found that family companies are more likely to achieve high performance than non-family companies. Our result supports $\mathrm{H} 1$, which proposes that family companies are positively associated with firm performance.

In respect of firm's characteristics and corporate governance factors as control variables, the coefficient of dividend is positive and significant at the level (.001), while leverage ratio has a negative and significant association with the company's performance. These findings are again consistent with previous studies (Anderson and Reeb, 2003a; Espinoza and Espinoza, 2012). Furthermore, the coefficient of board duality has a negative and significant effect on company performance.

Table 7. Company performance regression estimates for panel sample of companies

\begin{tabular}{lcccc}
\hline \multicolumn{1}{c}{ Variables } & Predicted sign & Coeff. & t-stat. & P-Value \\
\hline FAMI & + & .075 & 2.78 & $0.029^{* * *}$ \\
FSIZE & + & $2.15 \mathrm{e}-12$ & 0.09 & 0.929 \\
FDIVID & + & .1345 & 8.32 & $0.001^{* * *}$ \\
FLEVER & - & -.0727 & -2.90 & $0.004^{* * *}$ \\
BOARDSI & $?$ & -.0019 & -0.74 & 0.458 \\
BOARDD & $?$ & -.0366 & -2.47 & $0.013^{* * *}$ \\
BOARDI & + & -.0027 & -0.38 & 0.704 \\
MANAOW & + & .0456 & 0.76 & 0.449 \\
INSTITOW & + & -.0099 & -0.45 & 0.655 \\
Cons & .0927 & .0346 & 0.56 & 0.578 \\
Adjusted $\mathrm{R}^{2}$ & 0.41 & & & \\
F-Stat. & $10,355^{* * *}$ & & & \\
\hline
\end{tabular}

\section{Conclusions and Discussions}

This study empirically investigated the relationship between performance and family ownership in non-financial Jordanian companies over the period of three years, 2014 to 2016 . We found statistically significant evidence that family companies achieve higher performance than non-family companies. In this regard, the literature suggested two viewpoints on the association between company performance and family ownership: the convergence of interest and management entrenchment perspectives. Convergence of interest between the owners and outside investors occurs when the owner's holding is significant; an increase will reduce stockholders' need to monitor insiders, accordingly decreasing the need for entrenching insiders, increasing the incidence of information asymmetry between the insider and outsider investors. When investment decisions are more likely to be made to maximise the insiders' wealth at the expense of outsiders, outsiders will find it necessary to monitor owner-managers by expanding the level of company performance.

In general, the results are in line with the management entrenchment perspective, which proposes a positive relationship between company performance and family ownership. These findings should be of interest to policymakers, regulators and academics regarding the impact of family ownership on the performance not only in Jordan but also in other developing countries. Further, the findings of this study are likely to be of interest to investors since they introduce new empirical evidence about company performance in Jordan. In addition, the findings provide empirical evidence that enables managers to assess their achievement, in turn helping firms to improve investors' investments. Therefore, managers should give priority to developing suitable and complete progresses. The results reported in the study will assist managers wishing to understand more precisely how the ownership structure affects company performance. As with any study, this research has some limitations. First, it only focuses on Jordanian companies, thus the results do not reflect the characteristics of firms in other countries, even within the Middle East, because of Jordanian's unique liberalisation and other factors. Future studies might focus on other markets. Second, the sample of this study was only non-financial companies, due to the specific regulations pertaining to the financial sector; future studies could focus on that sector. 


\section{References}

1. Al-Akra, M., and Hutchinson, P. (2013). Family firm disclosure and accounting regulation reform in the Middle East: The case of Jordan. Research in Accounting Regulation, 25(1), 101-107.

2. Al-khabash, A. A., and Al-Thuneibat, A. A. (2008). Earnings management practices from the perspective of external and internal auditors: Evidence from Jordan. Managerial Auditing Journal, 24(1), 5880.

3. Al-Saidi, M., and Al-Shammari, B. (2013). Board composition and bank performance in Kuwait: an empirical study. Managerial Auditing Journal, 28(6), 472-494.

4. Ali, A., Chen, T.-Y., and Radhakrishnan, S. (2007). Corporate disclosures by family firms. Journal of Accounting and Economics, 44(1), 238-286.

5. Alqatamin, R., Ali, Z., and Arun, T. (2017). The effect of CEOs' characteristics on forward-looking information. Journal of Applied Accounting Research.

6. Alqatamin, R. M. (2018). Audit Committee Effectiveness and Company Performance: Evidence from Jordan. Accounting and Finance Research, 7(2), 48.

7. Anderson, R. C., and Reeb, D. M. (2003a). Founding-family ownership and firm performance: evidence from the SandP 500. the Journal of Finance, 58(3), 1301-1328.

8. Anderson, R. C., and Reeb, D. M. (2003b). Founding-family ownership and firm performance: evidence from the SandP 500. the Journal of Finance, 58(3), 1301-1327.

9. Arosa, B., Iturralde, T., and Maseda, A. (2010). Outsiders on the board of directors and firm performance: Evidence from Spanish non-listed family firms. Journal of Family Business Strategy, 1(4), 236245.

10.ASE, A. S. E. M. (2017). Companies Control Department classification.

11.Athanasakou, V., and Hussainey, K. (2014). The perceived credibility of forward-looking performance disclosures. Accounting and Business Research, 44(3), 227-259.

12.Barontini, R., and Caprio, L. (2006). The effect of family control on firm value and performance: Evidence from continental Europe. European Financial Management, 12(5), 689-723.

13.Chen, Q., Ding, S., Wu, Z., and Yang, F. (2016). Family control, international accounting standards, and access to foreign banks: Evidence from international entrepreneurial firms. Journal of Small Business Management, 54(2), 598-621.

14.Chen, S., Chen, X., and Cheng, Q. (2008). Do family firms provide more or less voluntary disclosure? Journal of accounting research, 46(3), 499-536.

15.Cucculelli, M., Mannarino, L., Pupo, V., and Ricotta, F. (2014). Owner-management, firm age, and productivity in Italian family firms. Journal of Small Business Management, 52(2), 325-343.

16.De Massis, A., Kotlar, J., Campopiano, G., and Cassia, L. (2015). The impact of family involvement on SMEs' performance: Theory and evidence. Journal of Small Business Management, 53(4), 924-948.

17.Espinoza Aguiló, T. I., and Espinoza Aguiló, N. F. (2012). Family business performance: evidence from Mexico. Cuadernos de Administración, 25(44), 39-61.

18.Giovannini, R. (2010). Corporate governance, family ownership and performance. Journal of Management and Governance, 14(2), 145-166.

19.Habbershon, T. G., Williams, M., and MacMillan, I. C. (2003). A unified systems perspective of family firm performance. Journal of business venturing, 18(4), 451-465.

20. Hutchinson, M., and Gul, F. A. (2004). Investment opportunity set, corporate governance practices and firm performance. Journal of corporate finance, 10(4), 595-614.

21.Kallamu, B. S., and Saat, N. A. M. (2015). Audit committee attributes and firm performance: evidence from Malaysian finance companies. Asian Review of Accounting, 23(3), 206-231.

22. Katmun, N. (2012). Disclosure quality determinants and consequences. Durham University.

23.Kim, P. K., and Rasiah, D. (2010). Relationship between corporate governance and bank performance in Malaysia during the pre and post Asian financial crisis. European Journal of Economics, Finance and Administrative Sciences, 21(1), 39-63.

24.Lubatkin, M. H., Schulze, W. S., Ling, Y., and Dino, R. N. (2005). The effects of parental altruism on the governance of family-managed firms. Journal of organizational behavior, 26(3), 313-330. 
25.Lückerath-Rovers, M. (2013). Women on boards and firm performance. Journal of Management and Governance, 17(2), 491-509.

26.Memili, E., Fang, H., Chrisman, J. J., and De Massis, A. (2015). The impact of small-and mediumsized family firms on economic growth. Small Business Economics, 45(4), 771-785.

27.Miller, D., and Breton-Miller, L. (2006). Family governance and firm performance: Agency, stewardship, and capabilities. Family business review, 19(1), 73-87.

28.Minichilli, A., Corbetta, G., and MacMillan, I. C. (2010). Top management teams in family-controlled companies:'familiness', 'faultlines', and their impact on financial performance. Journal of Management studies, 47(2), 205-222.

29.Morck, R., Shleifer, A., and Vishny, R. W. (1988). Management ownership and market valuation: An empirical analysis. Journal of financial economics, 20, 293-315.

30.Ntim, C. G., and Oseit, K. A. (2011). The impact of corporate board meetings on corporate performance in South Africa. African Review of Economics and Finance, 2(2), 83-103.

31.Peng, M. W., and Jiang, Y. (2010). Institutions behind family ownership and control in large firms. Journal of Management studies, 47(2), 253-273.

32.Ponnu, C. H. (2008). Corporate governance structures and the performance of Malaysian public listed companies. International Review of Business Research Papers, 4(2), 217-230.

33.Praptiningsih, M. (2009). Corporate governance and performance of banking firms: evidence from Indonesia, Thailand, Philippines, and Malaysia. Jurnal Manajemen dan Kewirausahaan (Journal of Management and Entrepreneurship), 11(1), pp. 94-108.

34.San Ong, T., and Gan, S. S. (2013). Do family-owned banks perform better? A study of Malaysian banking industry. Asian Social Science, 9(7), 124.

35.Schulze, W. S., Lubatkin, M. H., and Dino, R. N. (2003). Toward a theory of agency and altruism in family firms. Journal of business venturing, 18(4), 473-490.

36.Sufian, F., and Habibullah, M. S. (2010). Does economic freedom fosters banks' performance? Panel evidence from Malaysia. Journal of Contemporary Accounting and Economics, 6(2), 77-91.

37.Villalonga, B., and Amit, R. (2006). How do family ownership, control and management affect firm value? Journal of financial economics, 80(2), 385-417.

38.Wan-Hussin, W. N. (2009). The impact of family-firm structure and board composition on corporate transparency: Evidence based on segment disclosures in Malaysia. The International Journal of Accounting, 44(4), 313-333.

39.Wang, D. (2006). Founding family ownership and earnings quality. Journal of accounting research, 44(3), 619-656. 